ISSN 0258-7122 (Print), 2408-8293 (Online)

Bangladesh J. Agril. Res. 44(3): 493-499, September 2019

\title{
POPULATION FLUCTUATION OF JASSID, AND SHOOT AND FRUIT BORER OF OKRA
}

\author{
A. MOHAMMAD ${ }^{1}$, S. N. ALAM ${ }^{2}$, M. R. U. MIAH ${ }^{3}$ \\ M. R. AMIN ${ }^{4}$ AND R. S. SMRITI ${ }^{5}$
}

\begin{abstract}
A field study was conducted at the research field of Entomology Division, Bangladesh Agricultural Research Institute (BARI), Gazipur during April to July, 2016 to measure the population fluctuation of jassid (Amrasca biguttula biguttula), and shoot and fruit borer of okra (Earias vittella). Results revealed that jassid was always found in okra leaf during the whole study period. The highest jassid population was found during June and population reduced at the last week of July. Jassid population had significant positive relationship with temperature and significant negative relationship with relative humidity and rainfall. The weather parameters contributed $63.1 \%$ abundance of jassid population. But temperature had the most important effect which contributed $31.4 \%$ population fluctuation of jassid. Okra shoot and fruit borer population was the lowest during May and the highest at the end of June. There were nonsignificant relationship between okra shoot and fruit borer population and weather parameters. Multiple regression equation exerted $15.2 \%$ effect of weather parameters on okra shoot and fruit borer population abundance.
\end{abstract}

Keywords: Amrasca biguttula biguttula, Earias vitella, Temperature, Relative humidity, Rainfall.

\section{Introduction}

Okra (Abelmoschus esculentus L.) is a favourite vegetable in Bangladesh and is widely grown in tropical and subtropical regions (Obeng and Sackey, 2003; Oyelade et al., 2003). In Bangladesh, okra is produced mainly in the kharif season but it can be grown throughout the year. In the year 2014-2015, the total production of okra was 51.8 thousand tons from 11.4 thousand hectares of land with an average yield of 4.56 tha $^{-1}$ (BBS, 2015). The yield is very low compared to other countries.

Okra production in Bangladesh is affected by many factors, among them insect pest attack is major one. Nineteen insect species and four mite species have been reported on okra (Anon., 2000). These insect pest complex damages the crop during their different growth stages, right from germination to harvest and

${ }^{1}$ Scientific officer, Entomology section, Horticulture Research Centre, Bangladesh Agricultural Research Institute (BARI), Gazipur, ${ }^{2}$ Chief scientific officer, Entomology Division, BARI, Gazipur, ${ }^{3 \& 4}$ Department of Entomology, Bangabandhu Sheikh MujiburRahman Agricultural University (BSMRAU), Gazipur, ${ }^{5}$ Department of Soil Science, BSMRAU, Gazipur, Bangladesh. 
resulting lower yields (Gulati, 2004). The yield losses due to insect pests have been reported up to $69 \%$ (Mani et al., 2005).Among the insect pests, jassid (Amrasca biguttula biguttula Ishida) and okra shoot and fruit borer (OSFB) (Earias vittella) are the most serious pests and major limiting factors in okracultivation (Rahman, 1983). Jassid infestation begins at very early stages of crop growth and continues up to harvest depending upon agro-climatic conditions (Faleiro and Rai, 1985). The nymphs and adults suck the sap from under side of leaves and cause phytotoxic symptomsknown as hopper burn which results in complete desiccation of plants. The insect has been reported in okra throughout the year (Senapati and Khan, 1978). Okra shoot and fruit borer larvae cause damage both in vegetative and reproductive phase of the crop. When the crop is young, larvae bore into the tender shoots and feed on the internal tissue. In reproductive stage, larvae bore into the flower buds and fruits. For this reason, infested flower buds drops off and fruits become deformed resulting low market value (Dahiya et al., 2008).

Knowledge on the population fluctuation of jassid and shoot and fruit borer throughout the growing season of okra is very much important prior to develop their sound IPM program. Therefore, this study was undertaken to measure the population dynamics of jassid, and shoot and fruit borer of okra in relation to meteorological factors.

\section{Materials and Methods}

The field study was laid out in a Randomized Complete Block Design (RCBD) with three replications in the field of the Entomology Division, Bangladesh Agricultural Research Institute. The unit plot size was $9 \mathrm{~m} \times 4 \mathrm{~m}$. The inter block distance was $2 \mathrm{~m}$ and inter plot distance was $1 \mathrm{~m}$. There were three blocks andeach block was composed of three experimental unit plots along with an untreated control plot. Five pheromone traps of okra shoot and fruit borer were set in the experimental at as equal distance $\left(108 \mathrm{~m}^{2}\right)$.

Number of jassid was counted and recorded every 3 days intervals during early morning from 5 leaves of randomly selected 5 plans plot $^{-1}$. Mean jassid numberleaf ${ }^{-1}$ was calculated by using the collected data from all plots. Population of adult okra shoot and fruit borer were counted from pheromone trap catches and recorded at 3 days interval. The mean number okra shoot and fruit borertrap ${ }^{-1}$ was determined from total trap catches. The weather data of temperature, relative humidity and rainfall during the experimental period were collected from the meteorological observatory section of Bangladesh Rice Research Institute (BRRI), Gazipur.

The relationship of weather parameters on the population abundance of jassid and OSFB were determined by simple regression. The combined effects of temperature, relative humidity and rainfall on the population abundance of 
insects were measured by using a Multiple Linear Regression Equation. All the analyses were performed using IBM SPSS statistics 21.

\section{Results and Discussion}

Population fluctuation of jassidis shown in Figure 1. Jassid population was slightly fluctuated throughout the season and took the highest peak (4.98 leaf $\mathrm{f}^{-1}$ ) during first week of June ( $7^{\text {th }}$ week after sowing).The second highest (4.96 leaf ${ }^{-1}$ ) population was observed at $1^{\text {st }}$ July and after that population declined. Jassid population was the lowest $\left(2.97\right.$ leaf $\left.^{-1}\right)$ during the last week of July $\left(14^{\text {th }}\right.$ week after sowing) when crop was at late harvesting stage and rainfall increased. Continuous rainfall hindered the population build-up of jassid as reported by Lal et al., 1990. Inee et al. (2000) observed that meteorological parameters played an important role on the population build-up of jassid and they found that maximum jassid population reached to the peak at the last week of May.

Present study showed significant positive relationship of jassid population with temperature $\left(\mathrm{y}=0.230 \mathrm{x}-2.437, \mathrm{R}^{2}=0.314, \mathrm{~F}_{1,20}=9.1, \mathrm{P}<0.01\right)$ but significant negative correlation with relative humidity $\left(\mathrm{y}=-0.042 \mathrm{x}+7.652, \mathrm{R}^{2}=0.42\right.$, $\left.\mathrm{F}_{1,20}=14.47, \mathrm{P}<0.01\right)$ and rainfall $\left(\mathrm{y}=-0.028 \mathrm{x}+4.550, \mathrm{R}^{2}=0.40, \mathrm{~F}_{1,20}=13.28\right.$, $\mathrm{P}<0.01$ ) (Fig. 2).All the regression coefficients were significant at $1 \%$ level. That means jassid population was increased with the increasing of temperature and decreased with increasing relative humidity and rainfall. Similar results were reported by Mahmood et al. (2002). During the study, the temperature, relative humidity and rainfall ranged from $26.7^{\circ} \mathrm{c}$ to $31.6^{\circ} \mathrm{c}, 66.5 \%$ to $95.5 \%$ and $0 \mathrm{~mm}$ to $38.8 \mathrm{~mm}$, respectively.

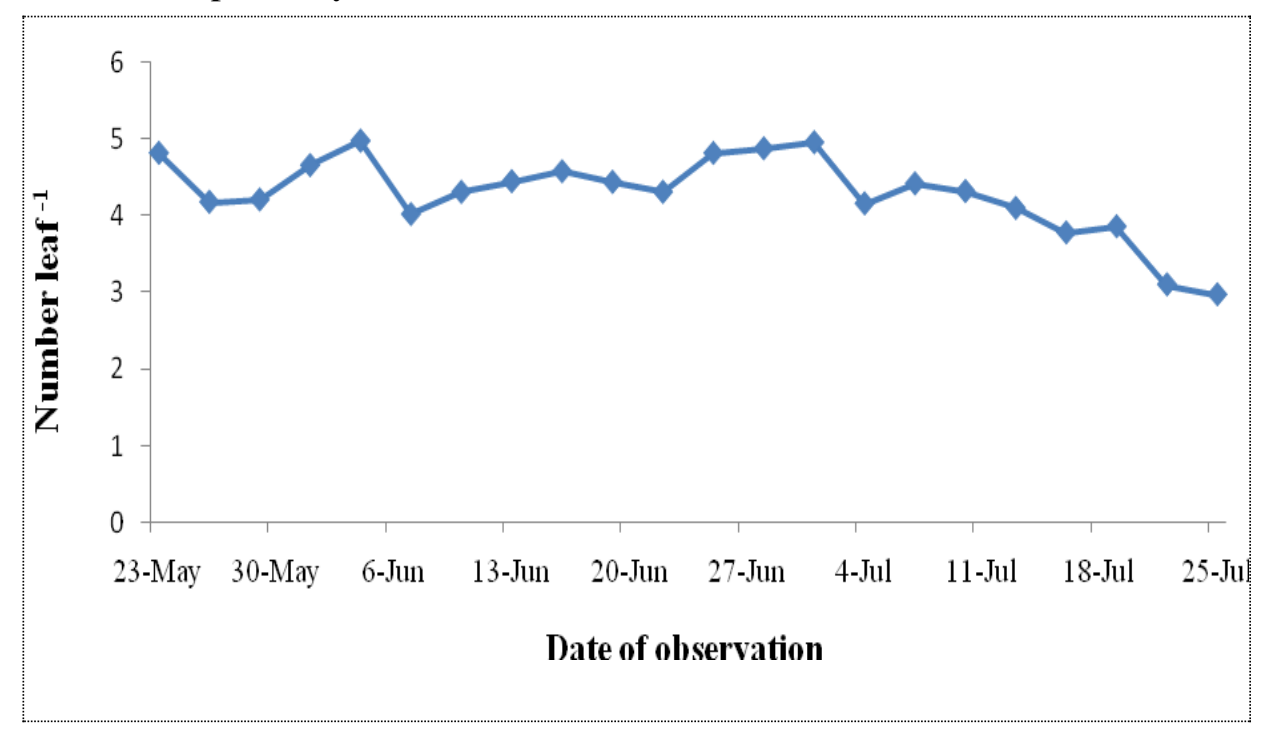

Fig.1. Population fluctuation of jassid on okra during 23 May to 25 July, 2016. 

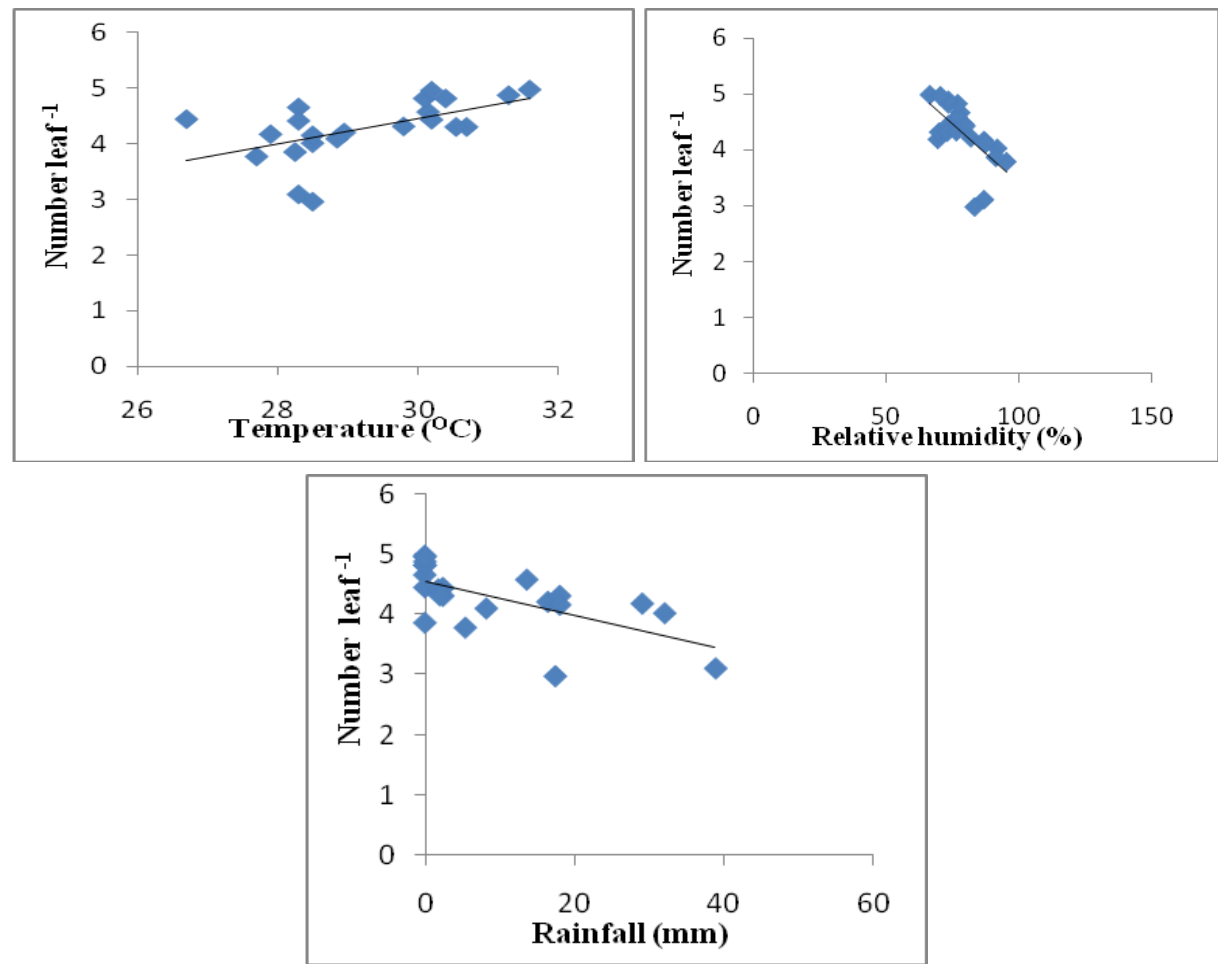

Fig. 2. Relationship of jassid population with temperature, relative humidity andrainfall.

Table 1. Multiple regression models along with coefficients of determination $\left(R^{2}\right)$ and the impact of weather parameters on the seasonal abundance of Jassid during April to July 2016

\begin{tabular}{|l|l|l|c|l|l|}
\hline \multicolumn{1}{|c|}{ Regression equation } & $\mathrm{R}^{2}$ & $100 \mathrm{R}^{2}$ & $\begin{array}{l}\text { Role of } \\
\text { Individual } \\
\text { factor }(\%)\end{array}$ & \multicolumn{2}{|c|}{ F statistic } \\
\hline $\mathrm{Y}=-2.437+0.230 \mathrm{X}_{1}$ & 0.314 & 31.4 & 31.4 & $\mathrm{~F}_{1,20}=9.1$ & $\mathrm{P}<0.01$ \\
\hline $\mathrm{Y}=4.015+0.097 \mathrm{X}_{1}-0.032 \mathrm{X}_{2}$ & 0.451 & 45.1 & 13.7 & $\mathrm{~F}_{2,19}=7.8$ & $\mathrm{P}<0.01$ \\
\hline $\mathrm{Y}=4.829+0.060 \mathrm{X}_{1}-0.027 \mathrm{X}_{2}-$ & 0.631 & 63.1 & 18 & $\begin{array}{l}\mathrm{F}_{3,18}= \\
10.3\end{array}$ & $\mathrm{P}<0.01$ \\
\hline $0_{0.020 \mathrm{X}_{3}}$ & & & \\
\hline
\end{tabular}

$\mathrm{Y}$, jassid population leaf ${ }^{-1}, \mathrm{X}_{1}$, temperature $\left({ }^{0} \mathrm{C}\right), \mathrm{X}_{2}$, relative humidity $(\%), \mathrm{X}_{3}$, rainfall ( $\mathrm{mm})$

Table 1 showed the effect of temperature, relative humidity and Rainfallwas $31.4 \%, 13.7 \%$ and $18 \%$ respectively, on jassid population abundance. The contribution of temperature with combination of relative humidity revealed $45.1 \%$ abundance. The multiple linear regression analysis showed that the 
weather parameters together contributed $63.1 \%$ abundance of jassid population. All the equations were insignificant at $1 \%$ level.

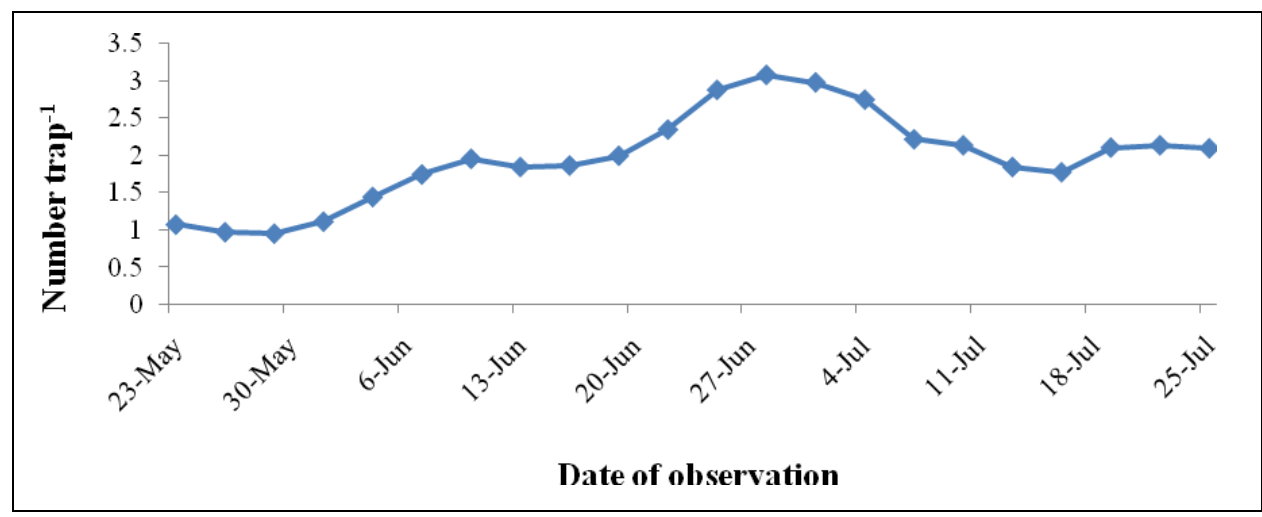

Fig. 3. Population fluctuation of okra shoot and fruit borer during 23 May to 25 July, 2016.

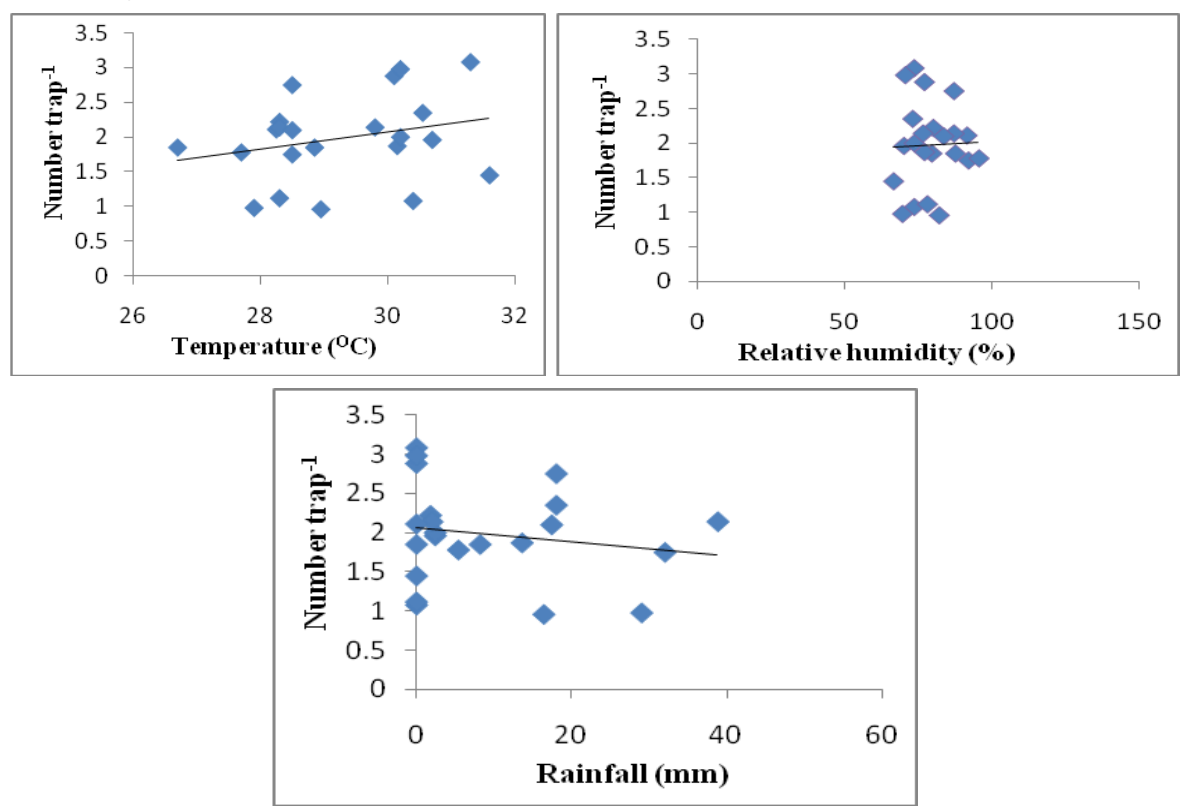

Fig. 4. Relationship ofokra shoot and fruit borer population with temperature, relative humidity and rainfall.

Population fluctuation of okra shoot and fruit borer is shown in Figure 3. Okra shoot and fruit borer population was low during early crop stage and found the lowest $\left(0.96\right.$ trap $\left.^{-1}\right)$ during the last week of May $\left(6^{\text {th }}\right.$ week after sowing $)$. After that population was gradually increased with single fall and reached to the peak (3.08 $\left.\operatorname{trap}^{-1}\right)$ during the last week of June (10 ${ }^{\text {th }}$ week after sowing). After June population decreased up to third week of July and again slightly increased during 
last week of the same month. Almost similarly, Dutta and Saha (1990) observed the highest population of okra shoot and fruit borer in the month of May and June.

Present study revealed that okra shoot and fruit borer population was positively correlated with mean temperature $\left(\mathrm{y}=0.124 \mathrm{x}-1.649, \mathrm{R}^{2}=0.068, \mathrm{~F}_{1,20}=1.4, \mathrm{P}=\right.$ $0.24)$ and relative humidity $\left(\mathrm{y}=0.002 \mathrm{x}+1.821, \mathrm{R}^{2}=0.0006, \mathrm{~F}_{1,20}=0.013, \mathrm{P}=\right.$ $0.91)$ but negatively correlated with rainfall $\left(\mathrm{y}=-0.009 \mathrm{x}+2.053, \mathrm{R}^{2}=0.028, \mathrm{~F}_{1,20}\right.$ $=0.577, \mathrm{P}=0.46)$ (Fig. 4). All the regression coefficients were non-significant. Dutta and Saha (1990) reported increased incidence of E.vittella with the increasing temperature and relative humidity.

Table 2.Multiple regression models along with coefficients of determination $\left(R^{2}\right)$ and the impact of weather parameters on the seasonal abundance of OSFB during April to July 2016

\begin{tabular}{|c|c|c|c|c|c|c|}
\hline Regression equation & $\mathrm{R}^{2}$ & $\begin{array}{c}100 \\
\mathrm{R}^{2}\end{array}$ & $\begin{array}{c}\text { Role of } \\
\text { individual }\end{array}$ & \multicolumn{3}{|c|}{ F statistic } \\
\hline$Y=-1.649+0.124 X_{1}$ & 0.068 & 6.8 & 6.8 & $\mathrm{~F}_{1,20}=1.4$ & $\begin{array}{l}\mathrm{P} \\
0.24\end{array}$ & $=$ \\
\hline $\begin{array}{l}Y=-6.898+0.232 X_{1}+ \\
0.026 X_{2}\end{array}$ & 0.135 & 13.5 & 6.7 & $\mathrm{~F}_{2,19}=1.5$ & $\begin{array}{l}\mathrm{P} \\
0.25\end{array}$ & $=$ \\
\hline $\begin{array}{l}\mathrm{Y}=-6.610+0.219 \mathrm{X}_{1}+ \\
0.028 \mathrm{X}_{2}-0.07 \mathrm{X}_{3}\end{array}$ & 0.152 & 15.2 & 1.7 & $F_{3,18}=1.1$ & $\begin{array}{l}\mathrm{P} \\
0.38\end{array}$ & $=$ \\
\hline
\end{tabular}

$\mathrm{Y}$, OSFB population leaf ${ }^{-1}, \mathrm{X}_{1}$, temperature $\left({ }^{0} \mathrm{C}\right), \mathrm{X}_{2}$, relative humidity $(\%), \mathrm{X}_{3}$, rainfall $(\mathrm{mm})$

The multiple linear regression analysis showed that temperature individually contributed $6.8 \%$ population abundance of OSFB and its effect was insignificant. The temperature with combination of relative humidity contributed $13.5 \%$ abundance, which was statistically non-significant. The individual effects of relative humidity demonstrated $6.7 \%$ abundance. The individual effect of rainfall was $1.7 \%$. The weather parameters together contributed $15.2 \%$ abundance of OSFB and equations were insignificant (Table 2).

Present study showed population fluctuation of the jassid and OSFB in summer season. The highest jassid, and okra shoot and fruit borer population was found during June. The weather parameters showed significant effect on jassid population abundance but insignificant effect on okra shoot and fruit borer population abundance. 


\section{References}

Anonymous. 2000. Status of pest risk analysis. Directorate of plant protection, quarantine and storage, Ministry of Agriculture, Government of India. P. 321.

BBS. 2015. Year book of Agric. statistics of Bangladesh. Ministry of planning, Government of Peoples Republic of Bangladesh, Dhaka.

Dahiya, K. K., R. S. Rana, J. Beniwal and A. Kumar. 2008. Eco-friendly management of insects and diseases in cotton. Technical bulletin No.33, Directorate of Extension Education, Haryana Agricultural University, Hisar, India.P.36.

Dutta, A. K. and J. L. Saha. 1990. Insect pest management of winter planted cotton in coastal rice fallow of West Bengal. Tropical Pest Management. 36: 89-92.

Faleiro, J. R. and S. Rai. 1985. Determination of vulnerable stage of crop growth to leaf hopper attack on okra. Indian J. Entomol.47: 238-239.

Gulati, R. 2004. Incidence of Tetranychuscinnabarinus (Boisd.) infestation in different varieties of Abelmoschus esculentusL. Ann. Plant. Prot. Sci. India.12: 45-47.

Inee, G., B. C. Dutta and I. Gogoi. 2000. Seasonal abundance of cotton jassid, Amrasca biguttula biguttula Ishida on okra. J .Agric. Sci. India.13: 22-26.

Lal, H., M. S. Mahal, R. Singh and B. Singh. 1990. Influence of rainfall on population build-up of Amrasca biguttula biguttula (Ishida) on Cotton. J. Insect Sci. 3: 169-171.

Mahmood, M., S. I. Hussain, K. M. Khokar, G. Jeelani and M. Ahmad. 2002. Population dynamics of leaf hopper (Amrasca biguttula biguttula) on brinjal and effects of abiotic factors on its dynamics. Asian J. Plant Sci.1: 403-404.

Mani, M., A.Krishnamoorthy and C. Gopalakrishnan. 2005. Biological control of Lepidopterous pests of horticultural crops in India. Rev. Agric. Res. 26: 39-49.

Obeng, O. D. and J. Sacky. 2003. Filed evaluation of non-synthetic insecticides for the management of insect pest on okra Abelmoschas esculentous (L.) Monech in Ghana Ethupian J. Sci. 26: 145-150.

Oyelade, O. J., B. I. O. Adeomowaye and V. F. Adeomi. 2003. Influence of variety on protein, at contents and some physical characteristics of okra seeds. J. Food. Eng. 57: 111-114.

Rahman, M. S. 1983. Evaluation of some insecticides against the pest complex of okra.Indian J. Entomol.43: 283-287.

Senapati, B. and S. R. Khan. 1978. A note on population fluctuation of Amrasca biguttlulla biguttulla (Ishida) at Bhubaneswar. Indian J. Agril. Res. 12: 97-98. 
